\title{
Building blocks play: Model reconstruction, teacher's guidance and early childhood creativity
}

\author{
M. Masnipal \\ Faculty of Tarbiyah and Teacher Training, Universitas Islam Bandung, Indonesia \\ E-mail: masnipal@unisba.ac.id
}

\begin{abstract}
Article History
Submitted: February 14, 2020

Accepted: April 30, 2020

Published: May 20, 2020

DOI: $10.26555 /$ jecce.v3i1.1763
\end{abstract}

\begin{abstract}
Teachers in ECE (Early Childhood Education) should have the knowledge and skills in guiding children when playing blocks, but this is not shared by most PAUD teachers in Indonesia. Therefore, this study develops a block play model that refers to the PKPK model from Hirsch and Dodge with the adjustment of conditions in Indonesia. This research is a research and development (R\&D) that seeks to develop, refine (re-construct), test, and validate Masnipal-models that are easy for teachers to use and effectively develop children's creativity. This study begins with testing the PKPK model to a group of subjects to obtain data about the ability of teachers to understand and apply the model. After revisions and improvements, the model of reconstruction results was further tested. Research subjects were PAUD teachers in Cianjur ( $n=42)$ and Bandung $(n=78)$. Data collection uses observation and peer assessment techniques and data analysis uses descriptive analysis techniques. The novelty of this study is the resulting Masnipalmodel that facilitates PAUD teachers in Indonesia in guiding children to develop creativity through block play.
\end{abstract}

Keywords: blocks play model, childhood, creativity.

\section{Abstrak}

Guru PAUD seharusnya memiliki pengetahuan dan keterampilan dalam membimbing anak ketika bermain balok, namun hal tersebut tidak dimiliki oleh sebagian besar guru PAUD di Indonesia. Oleh sebab itu, penelitian ini mengembangkan model permainan balok yang mengacu pada model PKPK dari Hirsch dan Dodge dengan penyesuaian kondisi di Indonesia. Penelitian ini merupakan penelitian pengembangan (R\&D) yang berupaya untuk mengembangkan, menyempurnakan (re-konstruksi), menguji, dan memvalidasi modelMasnipal yang mudah digunakan guru dan efektif mengembangkan kreativitas anak. Penelitian ini diawali dengan pengujian model PKPK kepada suatu kelompok subjek untuk memperoleh data tentang kemampuan guru dalam memahami dan mengaplikasikan model. Setelah dilakukan revisi dan perbaikan, model hasil rekonstruksi selanjutnya diujikan lagi. Subjek penelitian adalah guru PAUD di Cianjur ( $n=42)$ dan Bandung $(n=78)$. Pengumpulan data menggunakan teknik observasi dan penilaian teman sejawat seta dianalisis menggunakan analisis teknisk analisis deskriptif. Kebaruan penelitian ini adalah dihasilkannya model-Masnipal yang memudahkan guru PAUD di Indonesia dalam membimbing anak mengembangkan krativitas melalui permainan balok.

Kata Kunci : model permainan balok, usia dini, kreativitas. 


\section{INTRODUCTION}

Creativity development is one of the attempts to improve the quality of human resources because it can give opportunities to individuals or the public to make constructive changes in improving and increasing quality of life. Creativity can be learned, manipulated purposely and be developed anytime anywhere, but experts believe that creativity development is best done since early age stage (Munandar. U, 1999; Sawyer. R. K, 2006; Sternberg. R. J. \& Williams. W. M., 1996).

Early childhood are having a great development in all aspects; physical, motoric, language, emotion, social, and cognitive. To reach optimal development, those aspects need stimulation from its environment. One of the activities to stimulate the development is through playing. Playing is a part of early child's life, through playing they explore and develop their whole potentials, including in improving their understanding, experience, and creativity. Besides a source of learning, playing can also be used to improve a child's learning process and results (Dockett. S. \& Fleer. M, 2000; Masnipal, 2013; Morrison G. S, 2012). By playing children also learn to develop their ability in socializing, language, mathematics, art, creativity, and academic skills (Hanline. M. F. \& Melton. S., 2010).

Block play is one type of game that early childhood like. This type of game can easily be found in kindergartens, like building blocks, lego, lasy, sand-water, plasticine, and clay. In block play, children can learn various skills through interactions with their peers or individually. In many countries, block play becomes a part of programs for early childhood education. Hollow block and unit block almost always available in kindergartens in Europe and United States, including blockspot. In Indonesia, almost all early childhood education institutions like taman kanak-kanak (kindergarten)) or raudhatul athfal (Islam kindergarten) provide block play as a media of learning for students. However, based on field observation, the block plays are still not maximally used as learning media to develop students' potentials. Data shows that this condition happen because most of the teachers don't have the ability and skill in guiding students to play with blocks.

Besides that, there are still a lot of teachers and parents who consider that playing with blocks is not as important as learning how to read, to write, and to count. This perception 
influences teachers' motivation in learning the technique of block play and they just let the students play by themselves without any guidance. Whereas block play have many benefits for students' development when used properly. Some researches show the importance of building blocks play for early age children's development, such as helping children in developing imagination, skills of manipulation, creative and dramatic experiences (Dodge. D. T. et al, 2002; Pankratz. L. M., 2015; Provenzo \& Brett, 1984; Wilson, 2018) increasing numerical competence (Bojorque. G. et al, 2018; S.A., Korucu, Napoli, Bryant, \& J.Purpura, 2018) increasing mathematics competence like counting, recognizing shapes, and mathematic language (Park, Chae, \& Boyd, 2008; Pirrone, Tienken, \& Di Nuovo, 2018; Simoncini et al., 2020). Besides that, There is a close connection between playing with blocks for preschool children and the ability of reading and mathematics (Hanline. M. F. \& Melton. S., 2010). Building blocks play can increase spatial skill development. In block play, children are naturally able to increase their ability in observing, communicating, experimenting, and constructing (Borriello \& Liben, 2018; Casey. B. M. et al, 2008; Cohen \& Emmons, 2017). The previous study also discovered that building blocks play is the basis of early civil engineering and architecture skills (Brairaktova. et al, 2011).

In some advanced countries, a lot of playing techniques are developed to help students in playing blocks. Two of them have been made as references by many until now, as developed by E. Hirsch and Dodge, Colker, and Heroman (Bullock, 1992; Dodge. D. T. et al, 2002; Hirsch. E, 1984; Hoorn. J. V. et al, 1993). Hirsch block play model consists of seven game stages by making use of dramatic play at the last stage reffering to Smilansky's sociodramatic play. The seven stages are (1) carrying and arranging blocks, before using; (2) building basic construction; (3) setting the bridge, connecting the second and the third blocks; (4) making fence; (5) decoration pattern and symmetric; (6) giving labels to the structure to play dramatic; and (7) playing dramatic. The weaknesses of Hirsch model viewed from its usage are that (1) it has to be done by experienced teachers, at least they should have prior knowledge of constructive game basic technique, while most teachers in Indonesia don't have that knowledge so they need to have a training in advance; (2) Hirsch model doesn't have usage instructions for teachers, including dramatic game and what kind of blocks to use; (3) it doesn't have game 
scenario to guide teachers and students in encountering every stage of the game, even though it has the stages of the game.

The other block play technique was developed by Dodge, Colker, and Heroman (Dodge. D. T. et al, 2002). Dodge technique has four block game stages that the students have to do. The four stages are (1) choosing and carrying blocks; (2) piling blocks and making roads; (3) connecting blocks to create structures; and (4) making elaborate constructions. Dodge suggests the target of developing creating thinking through block play, they are (1) flexibility in approaching the problem, (2) cause and effect exploration, (3) object classification, (4) comparing/measuring, (5) arranging objects in a series, (6) recognizing the pattern and being able to re-do, (7) showing position and room awareness, (8) using numbers and calculating, and (9) making images and interpreting them. The purpose of developing creative thinking with what the children are able to do in building block game (Dodge. D. T. et al, 2002) in the following table.

Table 1. 1. The Connection Between the Purpose of Developing Creative Thinking and Block Play

\begin{tabular}{|c|c|c|}
\hline No. & Purpose & What children do in block play \\
\hline 1. & $\begin{array}{l}\text { Problem approach } \\
\text { flexibility }\end{array}$ & $\begin{array}{l}\text { When a child wants a blue carpet to be the pool, he/she } \\
\text { comes to art area to get a blue paper. }\end{array}$ \\
\hline 2. & $\begin{array}{l}\text { Cause and effect } \\
\text { exploration }\end{array}$ & $\begin{array}{l}\text { If I add one more block, the structure of the building will } \\
\text { collapse. }\end{array}$ \\
\hline 3. & Object classification & Classifying blocks according to their types and shapes. \\
\hline 4. & Comparing/measuring & Getting a thread to measure two structures. \\
\hline 5. & $\begin{array}{l}\text { Arranging objects in a } \\
\text { series }\end{array}$ & Organizing blocks from big sizes to small sizes. \\
\hline 6. & $\begin{array}{l}\text { Recognizing pattern and } \\
\text { re-do }\end{array}$ & Creating a wall with long and short blocks \\
\hline 7. & $\begin{array}{l}\text { Showing position and } \\
\text { room awareness }\end{array}$ & $\begin{array}{l}\text { Saying: "I put animals in the fence. You make a road } \\
\text { outside the fence." }\end{array}$ \\
\hline 8. & $\begin{array}{l}\text { Using numbers and } \\
\text { calculating }\end{array}$ & $\begin{array}{l}\text { Reminding other students: "You don't have enough blocks } \\
\text { (pieces) to make a room/building. }\end{array}$ \\
\hline 9. & $\begin{array}{l}\text { Making images and } \\
\text { interpreting }\end{array}$ & Building a house and giving room names. \\
\hline
\end{tabular}

Dodge's block play technique is simpler compare to Hirsh's model, not only that it has fewer stages but also completed with the connection between purposes and what children do in developing their creativities. But this model doesn't have game scenarios that the teachers and students can follow so that it is difficult for inexperienced teachers to do, including how 
many meetings have to be done, what and where is the teachers' role; as observer, guide, or evaluator. Besides that, this model is general to all constructive plays device when every block has different levels of difficulties; there are so many types of blocks found in society.

The condition and problems of the two block play models became the basis of the study to develop a block play model that is suitable, fit, and easy to use by early childhood teachers in Indonesia. The developed model refer to the two models above. As the first step, the researcher tried to get data of the condition of early childhood teachers about block play. The survey results from some kindergartens in Bandung and Cimahi show that almost all early childhood teachers don't have the knowledge and skills in playing block play that they have difficulties to guide their students (Masnipal, 2008). Early childhood can play by themselves or without guidance, but based on Vygotsky's sociocultural theory (Vygotsky. L. S, 1978), the help from adult can improve zone of proximal development (ZPD) from actual ability based on independent effort on higher potential ability.

Initiated by the desire above, in 2008 the researcher did a study to develop a building block play that was believed to be more appropriate with the condition and ability of the teachers and early age children in Indonesia. The study tested 100 students of 5-6 years of age and 24 teachers in seven kindergartens in Bandung and Cimahi. The study resulted a constructive play technique using building blocks known as PKPK (Pengembangan Kreativitas Melalui Balok Membangun) (Masnipal, 2016).

PKPK model was developed mainly referring to Hirsch and Dodge, and it is completed with game scenario, game stages, teachers' duty, using instructions, and students' evaluation instrument. PKPK model uses guided play method, though in the next creative process the children play a free play. Some researchers use a lot of guided play in building block play (Ferrara.K. et al, 2011; Ramani, Zippert, Schweitzer, \& Applied, 2014). But free play method is also used to improve cognitive, social, imagination, and creativity (Bergen. D, 2002; Hyson. M, 2004; Otsuka \& Jay, 2011). As it uses guided play method, PKPK model is equipped with a technical guidance for the teachers before playing or guiding students.

What distinguish PKPK model to other similar models are (1) it is easier for teachers to use because it is completed with game scenario or detailed steps of the play for every meeting for every block groups; (2) teachers' duty and students' activity in every meeting are clear; (3) 
it doesn't have many game stages so that it is easier for students to play and it is easier for teachers to guide the students; (4) the way to play it is simpler so it can be used by children with special needs like children with autism, mild attention disorder, or learning disability; (5) the model can be used with different types of blocks, from simple to more difficult blocks. Besides that, to make it easier for teachers in guiding their students, the model is completed with technical guidance before the play, including their duties as observer, guide, assessor, and students' evaluation technique.

Reliability and effectiveness of PKPK model as a media to improve creativity has been tested through Figural Creativity Test or Torrance's Circle Test (1974) that was developed by Prof. Dr. Utami Munandar and friends in 1988 (Munandar. U, 1999). The test device was then adapted by the researcher to test kindergarten students of 5-6 years of age with the guidance from Prof. Dr. Kusdwiratri Setiono (Faculty of Psychology, Padjajaran University) and Prof. Dr. Utami Munandar (Faculty of Psychology, Indonesia University).

PKPK model consists of several components; special play scenario and creativity process, play stages of three different types of blocks, teachers' duty, assessing instrument, using guide, and technical guidance for teachers.

1. Play Scenario and Creativity Process

Play scenario and creativity process during PKPK model impelementation were determined by the teacher's role in preparing, guiding, observing, and assessing children during the process of playing blocks. In the picture below it is shown that M2 through M5 is a creative process that must be observed by the teacher and conducted an assessment. 


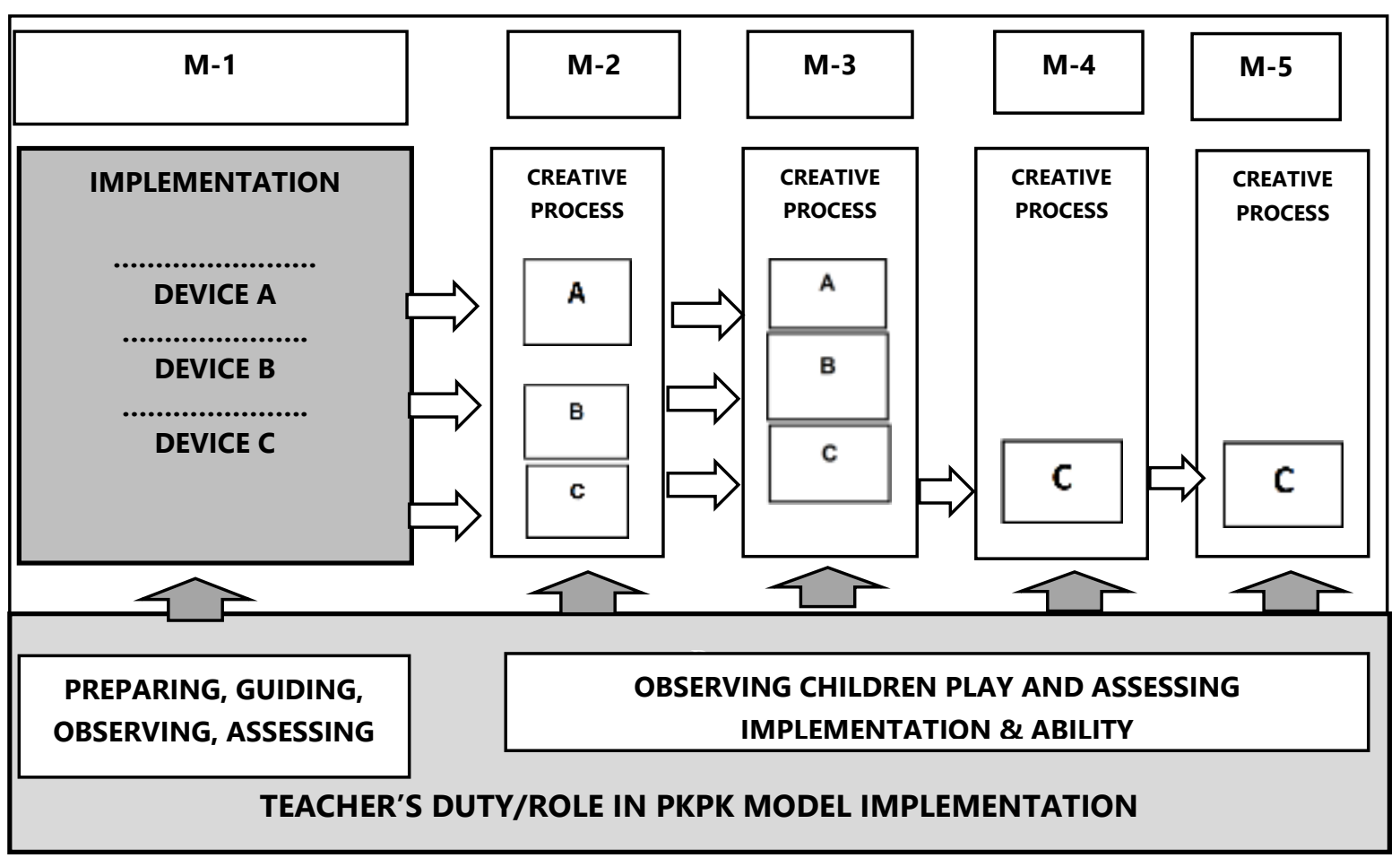

Figure 1.1. PKPK Model Game Scenario (Masnipal, 2008)

The picture in the scenario PKPK Model shows at the first play activity meeting (M1), the teacher guides the students to play from the preparation, implementation, and assessment of the three groups of building blocks $(A, B, C)$. Students are free to choose the type of block they like. The third group has different levels of difficulty, easy base level groups, middle level groups, and middle level groups with high difficulty levels. The task of the teacher in this 1st meeting is to guide, collect, and assess (checklist sheet). At the 2nd and 3rd meetings, it was a creative process, where students began to be released playing alone. The teacher's job is only to approve and approve the delay in the implementation of the game. At the 4 th and 5 th meeting is a creative process where students play using only groups of $C$ blocks, bearing in mind that $C$ type blocks have a higher level of difficulty.

2. Play Stages

PKPK model consists of three groups of blocks with different play stages; group A consists of BM-16, BM-49 and BM-104; group B consists of BH-55, BT-83, GB-86, BS- 145; and group C consists of MOBIS 60 and L-100. The three groups have different levels of difficulty. A blocks are easier to play compare to B blocks so they are suitable for beginners, 
and $\mathrm{B}$ blocks are easier that $\mathrm{C}$ blocks. $\mathrm{B}$ and $\mathrm{C}$ blocks are more appropriate for students who are more advanced.

$A$ and $B$ block groups are designed in five stages of play, while $C$ group has six stages. Every play stages are designed based on the purpose of improving creative thinking. Teachers' Role in the Play.

The involvement of teachers or adults in learning activities or playing is very important. The younger the children are the bigger the adults' role is. Adult's guidance is especially needed to help children who are not independent yet. Besides that, according to Vygotsky (Vygotsky. L. S, 1978) adult's help or involvement can expand zone of proximal development (ZPD) as a gap between actual improvement that is shown through their ability in solving problems independently with higher level of ability potentials that a child can achieve with help (Sawyer, 2003). In other words, adult's help in building blocks play helps students in reaching each stage to higher stages.

Some studies show that creativity is always a social process, having interaction with other people will involve knowledge, action and language that are constructed socially (Elisondo. R, 2016). Creativity may appear because there is collaboration with other people, whether they are friends or adults like teachers (Sawyer. R. K, 2006); or because there is interaction and contact with other people (Csikszentmihalyi \& Sawyer, 2014);(TrawickSmith. J. et al, 2016).

Based on those views, the researcher believes that assistance or guidance from adults like teachers in building blocks play can improve the students' potential in creativity ability. With the guidance from the teachers especially at the beginning of the play will help students in going through every level to achieve creative process. Teachers' guidance at the beginning of the play may also reduce the possibility of obstacle like stress that may appear because there are some blocks that are difficult to arrange.

The teachers had three roles in block play using PKPK model, as observer, guide, and assessor. As an observer, teacher's job was to observe the process of the play; as a guide the teacher gave guidance to make sure the students were able to follow the whole scenario and every stage of the play correctly; and as an assessor the teacher assessed whether or not all the play stages could be done by the students according to the model's 
scenario. The three roles or duty were only conducted at the $M-1$ process or $M-2$ if at $M-$ 1 the students still had difficulty. This study also wanted to test whether or not the students were already able to follow all the play stages correctly that teacher's help or guidance was still needed at $\mathrm{M}-2$ or probably $\mathrm{M}-3$, before they are left to play by themselves to let creative process happen.

On the table, guidance or teachers' help is only given on the first meeting $(M-1)$, after that the students were given a chance to play on their own. This means that the creative process started to happen since $M-2$ and continued on. At the creative process, the teacher's role was only observing and no more involved in guiding process. The teacher only observed what creative product that the students were able to create from the block pieces. It was this creative product that showed the students' creative process improved.

3. Students assessment instrument

To make sure that the students were able to follow the entire play stages correctly. PKPK model used an observation checklist. This assessment sheet was used by the teacher right after the play at the first or second meeting.

4. Application Guide

To make sure that PKPK model could function effectively by the guide (teachers, parents), then the model was completed with an instruction that consisted of rational, goal, description, time, teachers' role, implementation of the activities (principles, target, teachers, playing groups, time of implementation, the nature of the activity, playing space, evaluation instrument).

5. Technical Guide

Technical guidance was given to candidates who would guide students in playing the game. The meeting was held once for 5 effective hours. In this activity the guides were given the knowledge and skill in implementing the model (understanding the scenario, game stages, the guides' roles, how to use the assessing instrument) and simulation of the game.

In 2016, PKPK model was introduced to the public for the first time. A lot of early childhood education institutions were interested in implementing PKPK model at their school. Until 2018, the researcher or the model developer had organized three trainings or technical 
guidance and was attended by 150 teachers in Bandung and Cianjur. But from the observation results at the time and after the technical guidance it was discovered that some teachers had difficulty in understanding the model. It was confirmed by the results of discussions with teachers who had applied the guided block play to the students. It can be concluded that the problems faced by the teachers in implementing the PKPK model are (i) difficulty in understanding the game scenario for three types of blocks at one time with different stages and lack of time; (ii) difficulty in understanding and applying the play guide. Considering the problems then an effort to correct or improvement the model was needed to make it easier and more effective to be implemented by teachers as play guides.

This research tried to solve the above problems and make corrections, improvements or reconstructions of PKPK model specification focusing on scenario, play stages, and application guide. The purpose of this research is to find out the problems that the teachers faced in understanding and applying the model: make revisions and reconstructions of the model; and do validations to get the desired model.

\section{METHOD}

This research was a research and development or R \& D (Akker J. V. D, 2006), with the following steps: research and data collection, improvement or correction of model design, model testing, model revision, implementation guide and technical guidance testing, further product revision, organization and model validation, and model perfecting.

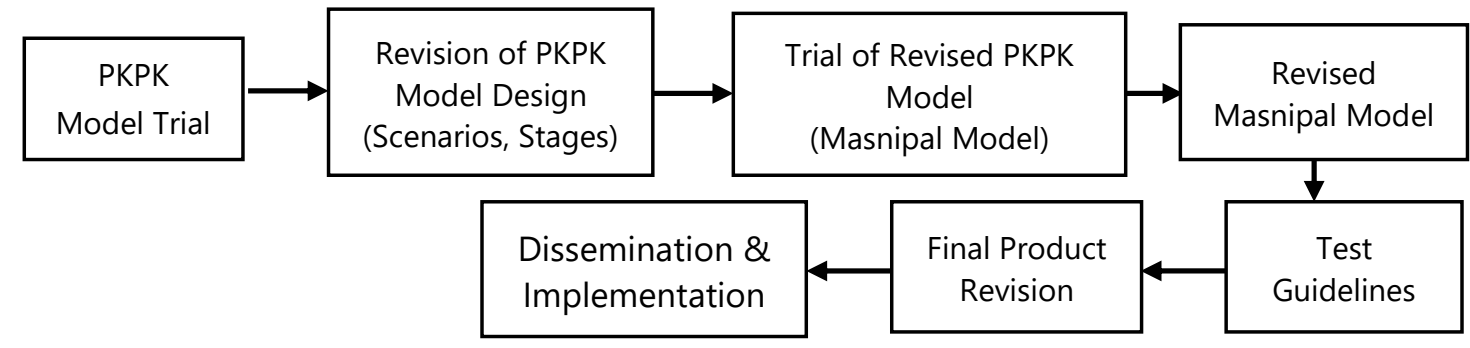

Figure 2.1. Research Scheme

Data collection was done using test and observation. Written test was given after technical guidance activity to assess the teacher's ability in understanding PKPK model. Observation checklist was used by peers to assess how far the teachers' ability in applying PKPK model to the students. 
The research and data collection were done by (a) observing and evaluating teachers ability in understanding PKPK model in technical guidance training activity. The training was held one time for 4 effective hours. Only teachers who followed the full training activity may be purposive subject for gathering data; (b) summarize and evaluate the results of peer assessments on teachers who implemented PKPK model to their students at their schools.

The results of the data collection were then used to make improvements or corrective of the model design by re-arranging the model especially on the problems that the teachers faced and they were scenario, game stages and implementation instructions. The improved model was then tested in training activity with different subject. The further test results were then used for revision and model improvement.

The research subjects for collecting the data were 42 Islam kindergarten (raudhatul athfal) teachers in three districts in Cianjur, they were districts of Cipanas, Sukaresmi, and Pacet. While the subjects for testing were 78 raudhatul athfal teachers in Bandung districts; Cicalengka sub-district, Nagrek, and Cikancung and they were willing to follow a technical guidance. The previous PKPK model was tested to teachers from Cianjur $(n=42)$, and test model (Masnipal Model) was tested to teachers from Bandung district $(n=78)$. Then, data analysis was performed using descriptive analysuis technique by the average difference test.

\section{RESULT AND DISCUSSION}

Teachers ability in understanding the procedures, stages, and scenario of model block play after following a technical guidance for PKPK Model and Test Model (Masnipal Model) are shown in the following table.

Table 3.1. Average Score of Teachers' Ability in Understanding PKPK Model and Test Model

\begin{tabular}{|c|c|c|c|}
\hline \multirow[b]{3}{*}{ No. } & \multirow[b]{3}{*}{ Measured Aspects } & \multirow{2}{*}{\multicolumn{2}{|c|}{ Average }} \\
\hline & & & \\
\hline & & $\begin{array}{l}\text { PKPK } \\
\text { Model }\end{array}$ & $\begin{array}{c}\text { Test } \\
\text { Model }\end{array}$ \\
\hline 1. & $\begin{array}{l}\text { Teachers' ability in understanding the procedure and scenario of the } \\
\text { game. }\end{array}$ & 0,59 & 0,73 \\
\hline 2. & Teachers' ability in understanding the stages of block game. & 0,87 & 0,90 \\
\hline 3. & $\begin{array}{l}\text { Teachers' ability in understanding their roles as observer, guide, and } \\
\text { assessor. }\end{array}$ & 0,81 & 0,85 \\
\hline 4. & Teachers' ability in using the model in game activity simulation. & 0,73 & 0,82 \\
\hline 5. & Teachers' ability in understanding how to play with A group blocks. & 0,77 & 0,85 \\
\hline 6. & Teachers' ability in understanding how to play with B group blocks. & 0,58 & 0,70 \\
\hline 7. & Teachers' ability in understanding how to play with $C$ group blocks. & 0,52 & 0,64 \\
\hline
\end{tabular}




\begin{tabular}{llll}
\hline 8. & Teachers' ability in assessing the students. & 0,79 & 0,82 \\
\hline 9. & Effectiveness in using the time. & 0,59 & 0,76 \\
\hline 10. & Teachers' ability in following model implementation instruction. & 0,55 & 0,73 \\
\hline
\end{tabular}

The test results above show that there was an increase in the teachers' ability in understanding the scenario, game stages, teachers' role, and implementation instructions and time in Test model compare to PKPK model in all aspects. The aspects that were below limit score of 0,6 like the ability to understand the scenario, the ability to understand how to play $B$ blocks, the ability to understand how to play with $\mathrm{C}$ blocks, the ability to follow the instruction and time improved and were above the limit score. This shows that Test model that was a result of revision and improvement was more effective to be used by teachers compare to PKPK model (before revised).

The teacher's ability to understand scenarios, stages of play, and how to use the beam game tool, assessing students is a requirement for creating effective games, so that it impacts on physical (subtle motoric), social, emotional, and cognitive development including creativity (Bullock, 1992). It also means that assistance or guidance provided by teachers who have the ability or technical skills to play with blocks can increase the level of potential abilities of higher children (Sawyer, 2003). Teachers' ability in applying PKPK model and Test Model (Masnipal Model) is shown in the following table.

Table 3.2. Average Score of Teachers' Ability in Applying PKPK Model and Test Model

No.

Measured Aspects

\begin{tabular}{cc}
\multicolumn{2}{c}{ Average } \\
\hline $\begin{array}{c}\text { PKPK } \\
\text { Model }\end{array}$ & $\begin{array}{c}\text { Test } \\
\text { Model }\end{array}$ \\
\hline 0,57 & 0,72 \\
\hline 0,65 & 0,79 \\
\hline 0,82 & 0,91 \\
\hline 0,57 & 0,74 \\
\hline 0,55 & 0,71 \\
\hline 0,74 & 0,80 \\
\hline 0,68 & 0,76 \\
\hline 0,58 & 0,73 \\
\hline
\end{tabular}

Based on the table, it was proven that the average score of teachers' ability in applying Test model had an increase compared to PKPK model in all aspects, especially aspect $1(0,57)$, 
$4(0,57)$ and $5(0,55), 8(0,58)$ that were below limit score became above limit score $(0,72 ; 0,74$; and 0,$71 ; 0,73)$. It shows that Test Model had better potency in increasing teachers' ability in applying the model to the students compare to PKPK model. In other words, the teachers were able to use Masnipal Model better so that their jobs in guiding the students were easier.

The effectiveness of guidance to young children in the block game also depends very much on the teacher's ability to apply the game techniques inward, using each type of block has its own schemes and steps. Collaboration and interaction in the process that teachers do with students when played can encourage the interaction of new ideas or their creativity (Csikszentmihalyi \& Sawyer, 2014; Sawyer. R. K, 2006)

Masnipal model as a result of revision and reconstruction was explain below.

1. Game Scenario and Creative Process

The revised and improved model produced three different game scenarios and creative processes for every block groups. 


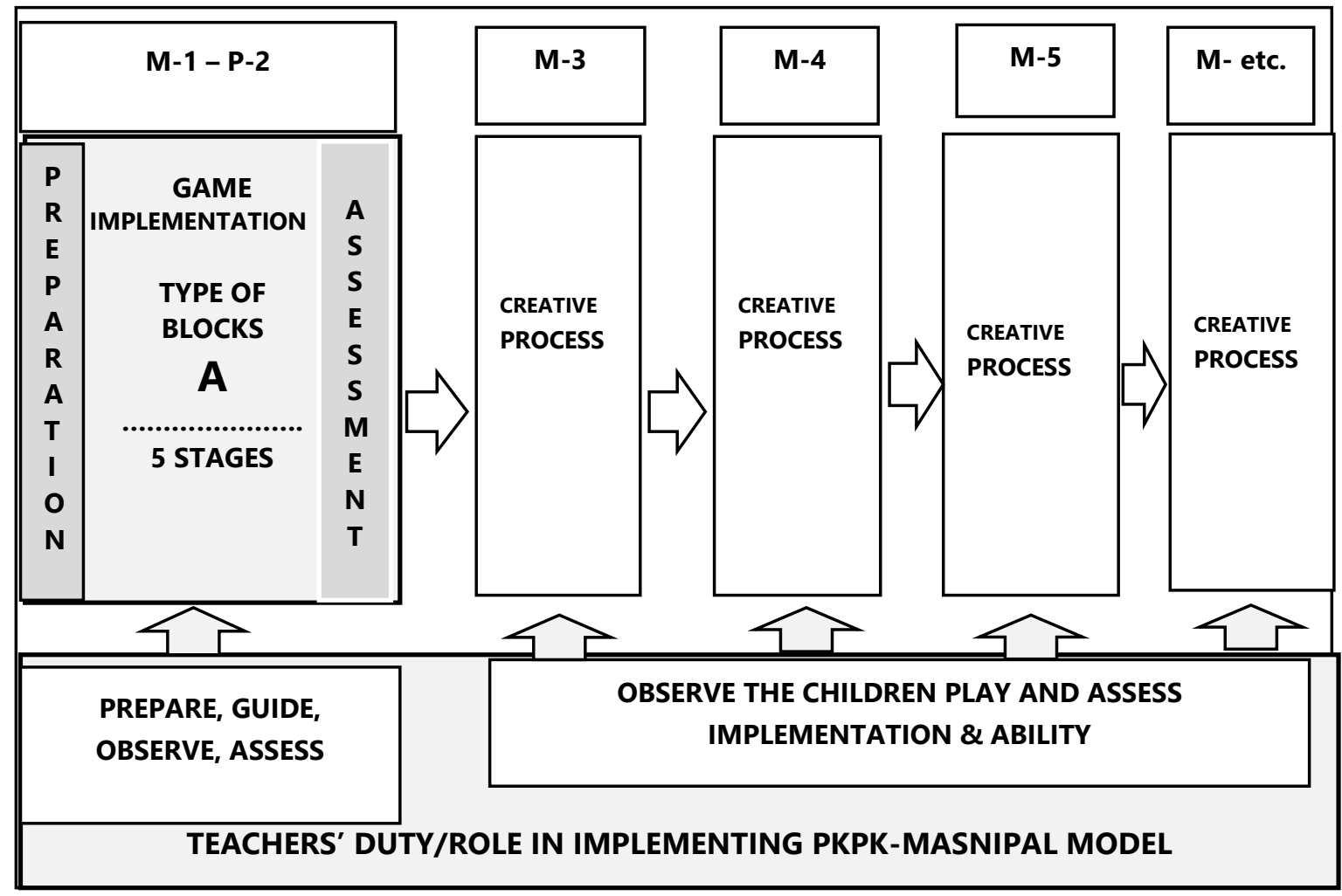

Figure 3.1. Game scenario and Creative Process for A group Block

The picture in this scenario PKPK-MASNIPAL Model shows at the 1st $(\mathrm{M}-1)$ and 2 (M-2) meetings, the teacher guides the students to play blocks for one group of blocks building $\mathrm{A}$ (BM-16, BM-49 and BM-104) with 5 steps. The game starts from preparation, implementation, and discussion. The beam group has several types of blocks with different amounts. The number of pieces of blocks provides opportunities for students to be creative. The greater the number of pieces used, the more variations the structure makes. The teacher's task in the 1st and 2nd meetings is to guide, approve, and assess. 3rd, 4th, 5th, etc. The play meeting, and so on, is a creative process, while students have the opportunity to make more variations in structure. The more creative the students, the more structure variations they create. The teacher's assignment at this meeting only discusses and evaluates for each meeting students can pass. 


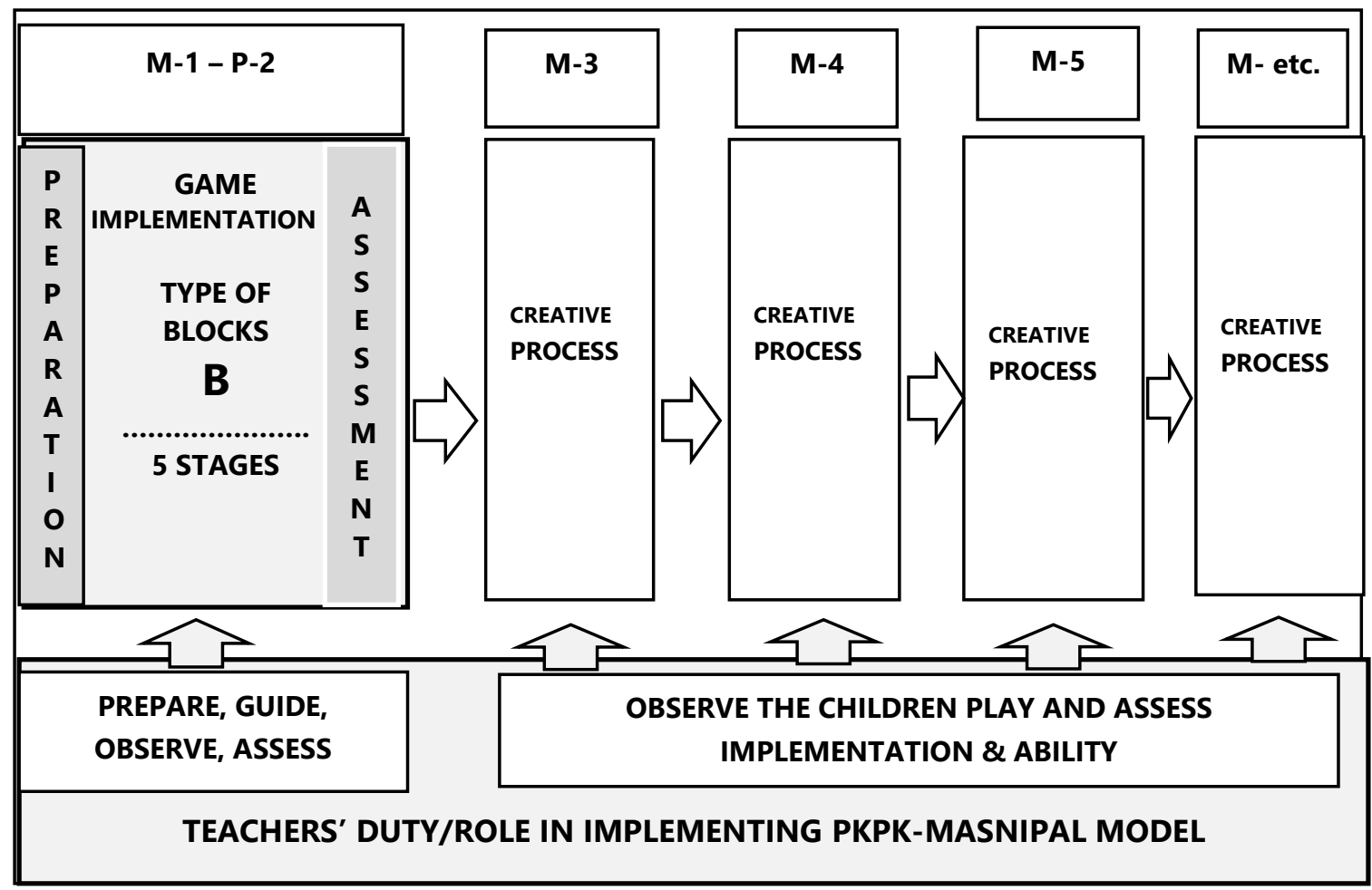

Figure 4.2. Game scenario and Creative Process for B group Blocks

The picture in this scenario shows at the 1st $(\mathrm{M}-1)$ and $2(\mathrm{M}-2)$ meetings, the teacher guides the students to play blocks for groups of beams building $\mathrm{B}(\mathrm{BH}-55, \mathrm{BT}-83, \mathrm{~GB}-86$, BS-145) with 5 stages. Play activities start from preparation, preparation to play, and discussion. The beam types in group B are different from the other groups. To make one get the structure the number of pieces has been determined and how to connect them. The teacher's task in the 1st and 2nd meetings is to guide, approve, and assess students. The 3rd, 4th, 5th, and so on play meetings, and so on, are creative processes provided by students and the opportunity to play by themselves according to their interests and creativity. The teacher's assignment at this meeting is held and agreed upon by students to ensure that every meeting can be held. 


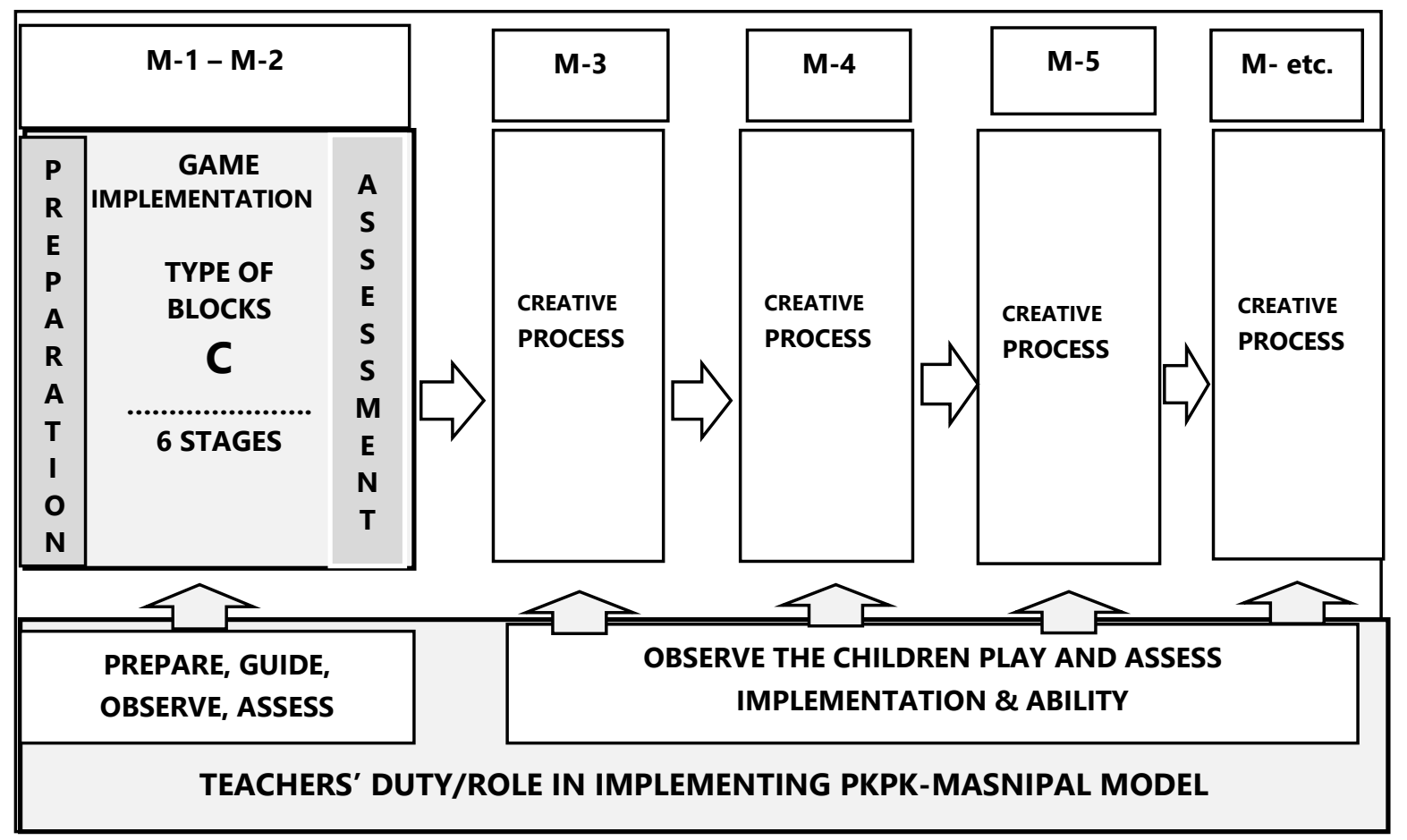

Figure 4.3. Game scenario and Creative Process for C group Blocks

The picture in the scenario shows at the first meeting $(M-1)$ and $2(M-2)$, the teacher guides the students to play blocks for one group of blocks building C (MOBIS 60 and Lasy 100) with 6 stages. Group $C$ has a different way of connecting with other groups, for Lasy 100 for example there are small $H$, large $H$, short sticks and long sticks, wheels, and so on. This type of game gives students the opportunity to create as many structures as possible for students' creativity. The task of the teacher in the 1st and 2 nd meeting is to guide, observe, and assess. The 3rd, 4th, 5th, and so on play meetings are the creative process. At this meeting students are given the broadest possible time and opportunity to play alone and develop creativity. The teacher's task is only to observe and assess to ensure each stage can be passed by students. Operationally, the scenario was elaborated for every type of blocks $(A, B, C)$, as follow.

Table 3.3. Activity Each Meeting

\begin{tabular}{ll}
\multicolumn{1}{c}{ Playing Time } & \multicolumn{1}{c}{ Activity } \\
\hline \multirow{3}{*}{ Meeting $-1 ;$} & $\begin{array}{l}\text { Teacher made preparation by setting the space and block play equipment } \\
\text { according to equipment groups. }\end{array}$ \\
\cline { 2 - 2 }$-2:(\mathrm{M}-1 ; \mathrm{M}-2)$ & Teacher guided the students and assessed students' ability. \\
\cline { 2 - 2 } &
\end{tabular}


M-3, M-4, M-5, etc. Teacher gave a chance for the students to play on their own so that the creative process may happen. The teacher's job at this point is just observing.

\section{Game Stages}

There was no fundamental addition or reduction to the game stage, for group $A$ and $B$ blocks each had 5 stages, and $C$ group had 6 stages. The only difference was that the time of applying was separated and not at the same time as previously. A, B, and $\mathrm{C}$ block groups were used separated with each game scenario. The purpose was (i) so that playing time was not in a hurry that it would interfere with creative process; (ii) to make it easier for teachers to organize the students. Beginner students could be given group A blocks, while more advanced students could use B and C group blocks which requires higher skills. This relates to statement that the games played, the types of films and games that must be played according to the experience, development and age of the child (Bullock, 1992).

a). Group A Play Stage

\begin{tabular}{|c|c|}
\hline STAGE 0 & $\begin{array}{l}\text { EXPLANATION ABOUT TYPES AND NUMBER OF BLOCK PIECES ALSO TECHNICAL } \\
\text { GUIDANCE ON HOW TO INSTALL, PUT TOGETHER AND COMBINE }\end{array}$ \\
\hline STAGE 1 & INSTALLING THE LONG POLE STRAIGHT \\
\hline STAGE 2 & CONNECTING BLOCK PIECES TO CREATE STRUCTURE \\
\hline STAGE 3 & $\begin{array}{l}\text { COMPLETING BUILDING STRUCTURE WITH EQUIPMENTS FOR FENCE, GARAGE, } \\
\text { CAGE, BRIDGE, ETC. }\end{array}$ \\
\hline STAGE 4 & $\begin{array}{l}\text { ADDING BUILDING STRUCTURES WITH DECORATION LIKE PEOPLE, HOME } \\
\text { APLIENCIES, VEHICLES, ANIMALS, PLANTS, ETC. }\end{array}$ \\
\hline STAGE 5 & GIVING NAMES TO THE BUILGINGS AND INTERPRETING THEM. \\
\hline
\end{tabular}

b). Group B Play Stage

\begin{tabular}{cl}
\hline STAGE 0 & SUPPLYING GAME EQUIPMENT AND THE RULES \\
\hline STAGE 1 & INTRODUCING THE NAMES, TYPES, MATERIALS/PIECES OF PLAYING DEVICES \\
\hline STAGE 2 & $\begin{array}{l}\text { INTRODUCING WAYS TO CONNECT DEVICES TOGETHER INTO A SIMPLE } \\
\text { ARRANGEMENT WITH DIFFERENT COMBINATIONS }\end{array}$ \\
\hline STAGE 3 & $\begin{array}{l}\text { MAKING SOME EXAMPLES OF BUILDING STRUCTURES (HOUSE, BUILDING, VEHICLES, } \\
\text { ANIMALS, PLANTS, FRUIT, ETC.). }\end{array}$ \\
\hline STAGE 4 & $\begin{array}{l}\text { ADDING BUILDING STRUCTURES WITH DECORATION LIKE PEOPLE, HOME } \\
\text { APLIENCIES, VEHICLES, ANIMALS, PLANTS, ETC. }\end{array}$ \\
\hline STAGE 5 & GIVING NAMES TO THE STRUCTURES AND INTERPRETING THEM. \\
\hline C). GrOUP C Play Stage \\
\hline STAGE 0 & SUPPLYING GAME EQUIPMENT AND THE RULES \\
\hline STAGE 1 & $\begin{array}{l}\text { INTRODUCING THE NAMES AND NUMBER OF BIG AND SMALL CONSTRUCTIVE } \\
\text { DEVICES, LONG AND SHORT STICKS, ETC. }\end{array}$ \\
\hline STAGE 2 & INTRODUCING WAYS TO CONNECT DEVICES INTO A SERIES OF STRUCTURE PARTS.
\end{tabular}




\begin{tabular}{cl} 
STAGE 3 & $\begin{array}{l}\text { INTRODUCING WAYS TO ASSEMBLE SOME ALREADY MADE STRUCTURES (VEHICLES, } \\
\text { HOUSES, ANIMALS, ROBOTS, ETC.). }\end{array}$ \\
\hline STAGE 4 & MAKING SOME STRUCTURE EXAMPLES (ANIMALS, WINDMILL, VEHICLES) \\
\hline STAGE 5 & GIVING NAMES TO THE STRUCTURES AND INTERPRETING THEM. \\
\hline STAGE 6 & DRAWING STRUCTURES THAT HAD BEEN MADE. \\
\hline
\end{tabular}

Group A and B blocks were designed in five play stages, while group C consisted of 6 stages. Every play stages were designed with the goal of developing creative thinking. The connection between play stages and the goal of developing creative thinking are as follow.

Table 3.4. Connection Between Game Stages with Developing Creative Thinking

\begin{tabular}{ccl}
\hline Play Stage & & \multicolumn{1}{c}{ Cognitive Development Goal } \\
\hline Stage 0 & - & \\
\hline Stage I & $\circ$ & Flexibility in approaching problems. \\
& $\circ$ & Classifying objects. \\
\hline Stage II & $\circ$ & Exploring cause and effect. \\
& $\circ$ & Comparing/measuring. \\
\hline Stage III & $\circ$ & Exploring cause and effect. \\
& $\circ$ & Comparing/measuring \\
& $\circ$ & Arranging objects in a series. \\
& $\circ$ & Pointing out position and space. \\
\hline Stage IV & $\circ$ & Pointing out position and space. \\
& $\circ$ & Recognizing pattern and able to repeat it. \\
& $\circ$ & Using numbers and counting. \\
\hline Stage V & $\circ$ & Mentioning names and functions of building parts. \\
\hline Stage VI & $\circ$ & Creative expressions. \\
\hline
\end{tabular}

\section{Teachers' Role in the Game}

Principally there are no changes for teachers' role in guiding the students play, as observer, guide, and assessor. But considering there are addition of meetings in implementing the model from 1 meeting into 2 or 3 meetings (for students with limitations) for one block group, hence adding longer work and time for teachers. Adding more meetings had a positive impact for a smooth, easy, and effective block play for both teachers and students.

Table 3.5. Teachers' Role in PKPK Model Block Play

\begin{tabular}{|c|c|c|}
\hline Stage & $\begin{array}{l}\text { Teachers' } \\
\text { Role }\end{array}$ & Teachers' Activities \\
\hline \multirow[t]{4}{*}{ Preparation } & \multirow{4}{*}{$\begin{array}{l}\text { As organizer } \\
\text { and facilitator }\end{array}$} & Preparing the space or room to play. \\
\hline & & Preparing the media/instrument to play. \\
\hline & & Organizing the children to play. \\
\hline & & $\begin{array}{l}\text { Giving information about the rules of the game (rules about how } \\
\text { to take the device and to put them back). }\end{array}$ \\
\hline
\end{tabular}




\begin{tabular}{|c|c|c|}
\hline \multirow[t]{5}{*}{ M-1 } & \multirow[t]{2}{*}{$\begin{array}{l}\text { Giving } \\
\text { guidance }\end{array}$} & $\begin{array}{l}\text { The teacher gave a guidance to the students about how to play } \\
\text { the PKPK model game according to the type of the device and } \\
\text { stage (once or twice depended on the students' ability). }\end{array}$ \\
\hline & & The teacher gave the students a chance to play. \\
\hline & \multirow{3}{*}{$\begin{array}{l}\text { Observing and } \\
\text { assessing } \\
\text { students }\end{array}$} & The teacher observed the students play. \\
\hline & & The teacher watched and listened to what the students say. \\
\hline & & The teacher assessed the students play on a checklist paper. \\
\hline M-2 & Observing & $\begin{array}{l}\text { The students were left to play by themselves/in a group freely, } \\
\text { relax, without teachers' interference, just observing. }\end{array}$ \\
\hline M-3 & Observing & Same above \\
\hline M-4 & & - \\
\hline M-5 & & - \\
\hline Etc. & & - \\
\hline
\end{tabular}

In carrying out their duties as observers, mentors and assessors of student games, ask a few questions for the teacher, give open-ended questions (end) questions); Regarding yourself as a meditor, the player, pulling out blocks of the beam correctly, uses the display to foster student interest (Manning, 2020; Wellhousen \& Giles, 2005; Williamson, Lovatt, \& Hedges, 2020).

4. Students Assessment

Technique and instrument for block play assessment did not change, but with the change in the scenario it added the number of students' assessment. At least from once became twice or three times of assessment for one block group. It was better as it gave more chances for students since not all students were fast in understanding the technique of block play especially for the ones with higher difficulty level.

5. Model Implementation Guide

Changes in game scenario also changed the guide for model implementation, especially on applying techniques, they are (a) the instructor had to show how to play the game while giving explanation step by step and gave a chance for the teachers to keep up; (b) it was better for the teachers to do the simulation in a group before they were trained individually; (c) the time to play was more flexible even though the students were still given a time limit.

6. Technical Guidance

Technical guidance was needed by the teacher before they gave a guidance to their students on how to play the block game. The technical guidance was given by the model developer starting from the knowledge of the types, functions, and 
characteristics of the blocks; how to assemble, make structures, to doing a simulation of the play with peers.

\section{CONCLUSION}

Based on the above study, it could be concluded that: First, Masnipal model (Test Model) has the ability in increasing teachers' understanding and ability in implementing block play to students compare to the previous one (PKPK model). In other words, it is easier and more effective for teachers to use Masnipal model in guiding their students to play with blocks compare to PKPK model. Second, the ease and effectiveness of applying Masnipal model by the teachers mainly because it had been revised, reconstructed, and improved especially in the game scenario, teachers' role, assessment time and implementation guide, and technical guidance.

\section{REFERENCES}

Akker J. V. D. (2006). Educational Design Research. New York: Routledge.

Bergen. D. (2002). The role of pretend play in children's cognitive development. Early childhood research and practive.

Bojorque. G. et al. (2018). Effectiveness of Building Block Program for Enhancing Equadorian Kindergarten Numerical Competencies. Early Childhood Research Quarterly, 231-241. https://doi.org/http://doi.org/10.1016/j.ecresq.2017.12.009

Borriello, G. A., \& Liben, L. S. (2018). Encouraging Maternal Guidance of Preschoolers' Spatial Thinking During Block Play. Child Development, 89(4), 1209-1222. https://doi.org/10.1111/cdev.12779

Brairaktova. et al. (2011). Engineering in young Children's Exploratory Play with Tangible materials. Children, Youth, and Environment Journal, 212-235.

Bullock, R. (1992). Learning through block play. Day Care and Early Education - Springer. Retrieved from https://link.springer.com/content/pdf/10.1007/BF01617077.pdf

Casey. B. M. et al. (2008). The Development of Spatial Skills Through Interventions Involving 
Block Building Activities. Cognition and Instruction Journal, 269-309. https://doi.org/http://doi.org/10.1080/07.370000802177177.

Cohen, L. E., \& Emmons, J. (2017). Block play: spatial language with preschool and school-aged children. Early Child Development and Care, 187(5-6), 967-977. https://doi.org/10.1080/03004430.2016.1223064

Csikszentmihalyi, M., \& Sawyer, R. K. (2014). In Csikszentmihalyi (Comp.) The Systems Model of Creativity. Netherlands: Springer.

Dockett. S. \& Fleer. M. (2000). Play and Pedagogy in Early Childhood, Bending and Rules. London: Harcourt Publishers International.

Dodge. D. T. et al. (2002). The Creative Curriculum for Preschool. Washington. DC: Teaching Strategis Inc.

Elisondo. R. (2016). Creativity is Always a Social Process. Creativity. Theories-ResearchApplications, 194-210. https://doi.org/http://doi.org/10.1515/ctra 2016-0013.

Ferrara.K. et al. (2011). Block talk:Spatial language during block play. Mind, Brain, and Education. Journal Compilation International, Mind, Brain, Educational Society and Blackwell, 143-151.

Hanline. M. F. \& Melton. S. (2010). The Relationsship Between Prescholl Block Play and reading and Maths Abilities in Early Elementary School: A Longitudinal Study of Children With and Without Disabilities. Journal Early Child Development and Care. https://doi.org/http://doi.org/10.1080/03004430802671171.

Hirsch. E. (1984). The Block Book. Revised ed. Washington. DC: National Association for the Education of Young Children.

Hoorn. J. V. et al. (1993). Play at the Center of the Curriculum. New York: Macmillan Publishing Company.

Hyson. M. (2004). The Emotional Eevelopment of Young Children. New York, NY: Teacher's College Press.

Manning, S. (2020). Blocks are educational: revealing discourses through early childhood policy 
illustrations. In Sight, Sound and Text in the History of Education (pp. 91-106). Routledge. https://doi.org/10.4324/9780429202650-6

Masnipal, M. (2008). Model Pengembangan Kreativitas Melalui Permainan Konstruktif Dalam Proses Pendidikan Anak Usia Dini (Studi terhadap Siswa Taman Kanak-Kanak di Bandung dan Cimahi. Bandung). Universitas Pendidikan Indonesia.

Masnipal, M. (2013). Siap menjadi Guru dan Pengelola Paud Profesional. Jakarta: PT. Elexmedia Komputindo-Gramedia.

Masnipal, M. (2016). Model Pengembangan Kreativitas Melalui Permainan Konstruktif dalam Meningkatkan Kemampuan Berpikir Kreatif Anak Usia Dini. Jurnal Pendidikan Islam Ta,Dib, 39-48.

Morrison G. S. (2012). Fundamentals Of Early Childhood Education, 5 Th Edition. New Jersey: Pearson Education, Inc.

Munandar. U. (1999). Kreativitas dan Keberbakatan. Jakarta: PT Gramedia Utama.

Otsuka, K., \& Jay, T. (2011). Understanding and supporting block play: video observation research on preschoolers' block play to identify features associated with the development of abstract thinking. Taylor \& Francis. Retrieved from http://shura.shu.ac.uk/13380/

Pankratz. L. M. (2015). Building With Block: Incorporating Picture Books To Motivate and Guide Block Play in Kindergarten. Journal Voices of Practitioners, 64-79.

Park, B., Chae, J. L., \& Boyd, B. F. (2008). Young children's block play and mathematical learning. Journal of Research in Childhood Education. https://doi.org/10.1080/02568540809594652

Pirrone, C., Tienken, C. H., \& Di Nuovo, S. F. (2018). The Influence of Building Block Play on Mathematics Achievement and Logical and Divergent Thinking in Italian Primary School Mathematics Classes Test for ASD View project Cortical excitability View project. Taylor \& Francis, 82(1), 40-58. https://doi.org/10.1080/00131725.2018.1379581

Provenzo, E. F., \& Brett, A. (1984). Creative block play. Day Care \& Early Education Journal, 11(3), 6-8. https://doi.org/10.1007/bf01616852

Ramani, G., Zippert, E., Schweitzer, S., \& Applied, S. P.-. (2014). Preschool children's joint block 
building during a guided play activity. Elsevier. Retrieved from https://www.sciencedirect.com/science/article/pii/S0193397314000628

S.A., S., Korucu, I., Napoli, A. R., Bryant, L. M., \& J.Purpura, D. (2018). Using block play to enhance mathematics and executive functioning: A randomized controlled trial. Early Childhood Research, 44(3), 181-191. https://doi.org/10.1016/j.ecresq.2018.04.006

Sawyer. R. K. (2006). Explaining creativity: the science of human innovation. New York: Oxford University Press.

Sawyer, R. K. (2003). Creativity and Development. New York: Oxford University Press.

Simoncini, K., Forndran, A., Manson, E., Sawi, J., Philip, M., \& Kokinai, C. (2020). The Impact of Block Play on Children's Early Mathematics Skills in Rural Papua New Guinea. International Journal of Early Childhood. Retrieved from https://link.springer.com/content/pdf/10.1007/s13158-020-00261-9.pdf

Sternberg. R. J. \& Williams. W. M. (1996). How to Develop Student Creativity. Virginia: Association for Supervision and Curriculum Development.

Vygotsky. L. S. (1978). The role of play in development. Harvard University Press.

Wellhousen, K., \& Giles, R. M. (2005). Building Literacy Opportunities into Children's Block Play What Every Teacher Should Know. Childhood Education, 82(2), 74-78. https://doi.org/10.1080/00094056.2006.10521350

Williamson, J., Lovatt, D., \& Hedges, H. (2020). Looking Beyond Books and Blocks: Peers Playing Around with Concepts (pp. 197-213). https://doi.org/10.1007/978-3-030-42331-5_13

Wilson, R. (2018). Nature and young children: Encouraging creative play and learning in natural environments. Retrieved from https://www.google.com/books?hl=id\&lr=\&id=KxdSDwAAQBAJ\&oi=fnd\&pg=PT7\&dq= Creative + block + play\&ots $=U p Y x E a 21 i E \& s i g=4 J x b g w A e k v c l l h s D d 0 o z Y R p h B 9 w$ 